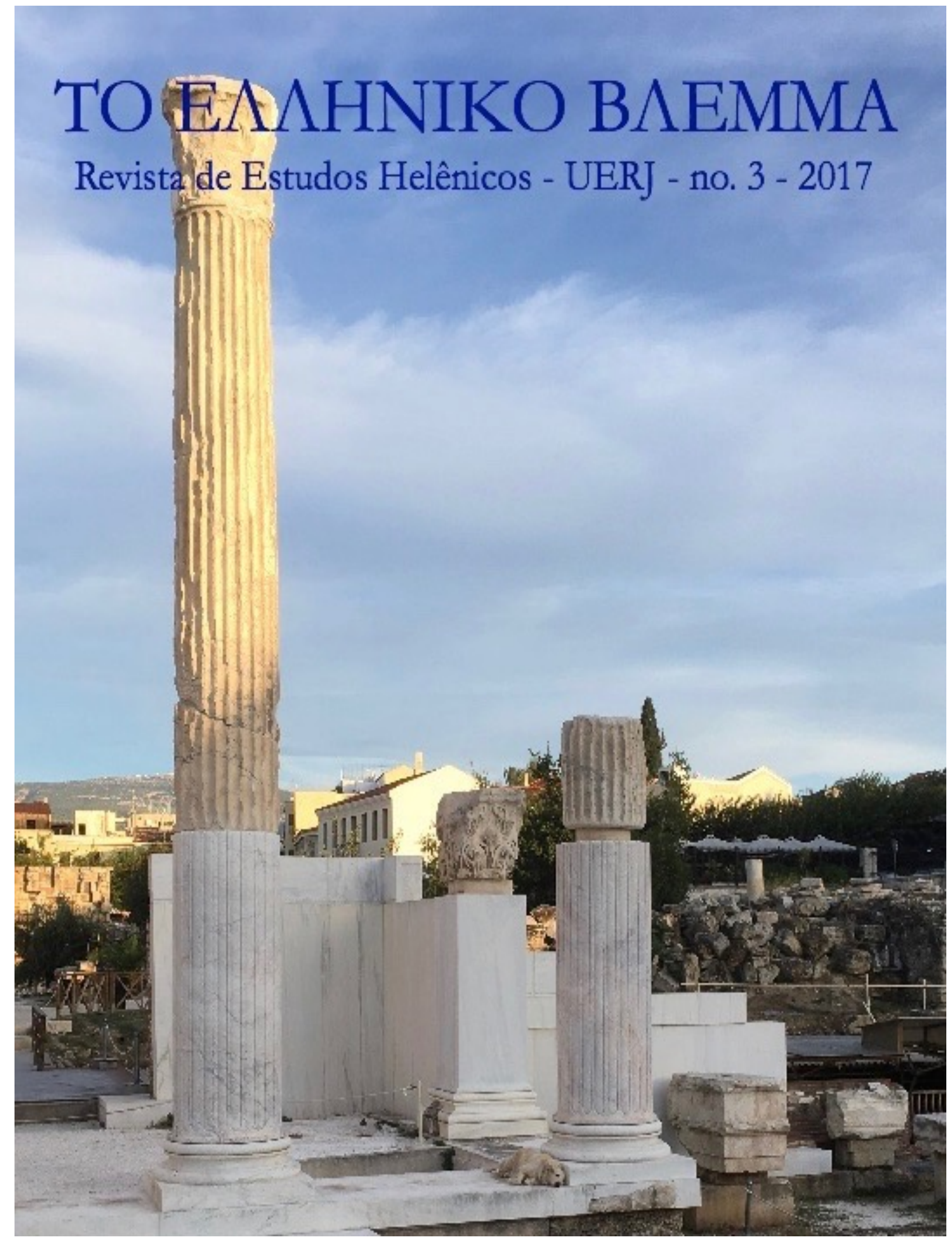




\title{
NATURALEZA E INICIACIÓN POÉTICA. ALGUNOS EJEMPLOS EN LA ÉPICA Y EN PLATÓN
}

\author{
Graciela Cristina Zecchin de Fasano - Universidad Nacional de La Plata
}

Las imágenes de la naturaleza acompañan las escenas de iniciación poética en diversos textos de la literatura griega clásica. El presente artículo analiza imágenes relacionadas con "la encina y la roca" y con las "sirenas, cigarras y musas" tanto en textos épicos como en el diálogo Fedro de Platón, para demostrar las consecuencias de la presencia de elementos de la naturaleza en la concepción de la creación poética.

PALABRAS CLAVE: Naturaleza-iniciación poética- épica-Platón

\section{NATURE AND POETIC INITIATION. SOME EXAMPLES IN THE EPIC AND PLATO}

\begin{abstract}
Nature images accompany the scenes of poetic initiation in various texts of the classical Greek literature. This article analyzes images related to "the oak and the rock" and to the "sirens, cicadas and muses" both in texts epic as in the dialogue Phaedrus of Plato, to demonstrate the consequences of the presence of elements of nature in the conception of the poetic creation.
\end{abstract}

KEY WORDS: Nature-Poetic Iniciation-Epic Poetry-Plato

La naturaleza ha recibido un papel de relevancia en casi todas las formas narrativas de la literatura griega clásica. Basta con mencionar su fuerte incidencia en los símiles de Míada o en la composición de lugares en los apólogos de Odisea, ya que las interpretaciones sobre su función y características han sido proficuas y numerosísimas. Hay un aspecto más restringido que resulta interesante analizar y que está relacionado con la vinculación entre la naturaleza y la creación poética en los momentos en que se inicia esa creación, ya sea ésta concebida como simple canto o como "artefacto" o producto. Pretendo reflexionar sobre dos tipos de imágenes de la naturaleza altamente significativas porque permiten conectar efectivamente afirmaciones épicas, muy particulares, sobre el quehacer poético y el lenguaje, con el discurso filosófico. Me refiero a las imágenes de la encina y la roca, por un lado; y a las que emparentan cigarras, sirenas y musas, por otro.

\section{La encina y la roca}

Hesíodo luce una oposición dialéctica como principio constructivo a través del cual expresa su relación poética con Homero. La impronta de una emulación "celosa" de Homero aparece como primer componente en el hecho de que Hesíodo no es un lector "intoxicado" o fascinado por Homero (PUCCI, 1987, p.195). Su poesía soslaya el efecto placentero, que es un objetivo prioritario en la épica homérica, porque está ocupada por la expresión de la verdad. La escena de autopresentación que preside Teogonía impone una iniciación ritual con paisaje pastoral, en el que se exagera el tono local: sus musas heliconidas hacen explícito el privilegiado trato entre ellas y el poeta. La composición de un himno inicial expone no sólo una clara posición divergente con Homero, sino también un campo temático de índole sagrada en que la concepción temporal adquiere una vastedad inusitada, aunque el poeta intenta 
aplicar un incipiente concepto histórico, ya que no compone catálogos como Homero, 1 sino que compone "genealogías". De igual modo, la poesía hesiódica propone un más allá en el decir, un discurso de tipo profético: ${ }^{2}$

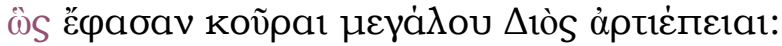

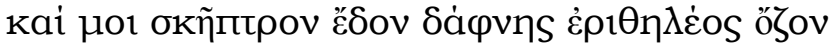

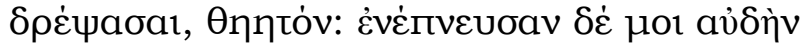

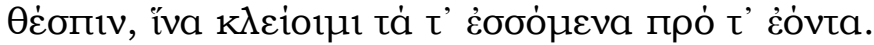

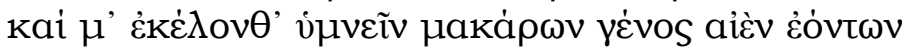

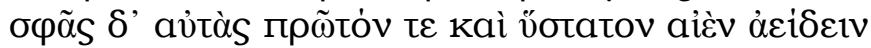

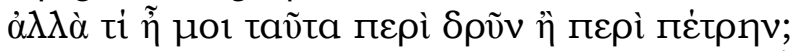

HESÍODO, Teogonía 29-35

Asi hablaron las veraces hijas del gran Zeus. Me concedieron como cetro una rama floreciente de laurel, digna de admiración, luego de cortarla. Me insuflaron una voz de inspiración divina para que celebrase lo pasado y lo porvenir. Me impulsaron a celebrar en un himno a la estirpe de los bienaventurados, que viven para siempre, $y$ a que les cantase a ellas siempre al principio y al final, sino ¿qué significan estas cosas para mi en torno de una encina o de una roca?

Dos elementos resultan relevantes en estos versos. El primer elemento se deriva del hecho de que Hesíodo extiende el tiempo épico al futuro, un tiempo reservado en Homero sólo para la profecía, que suele ser expresada como una serie alternativa de opciones. ${ }^{3}$ Por otra parte, Hesiodo no necesita deliberar qué contenido narrará primero, porque las musas establecen que serán el principio y el final de su composición. El segundo elemento lo constituye el paisaje introducido con la encina y la roca. Se trata de una mínima incidencia, pero su relevancia deriva de reproducir el paisaje de la conversación frustrada más dolorosa de Ilíada, la que Héctor imagina -antes de enfrentar a Aquiles- como un amoroso diálogo con su oponente:

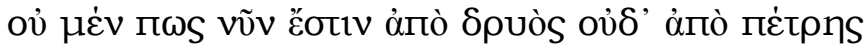

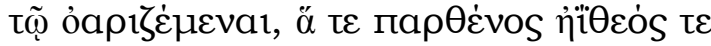

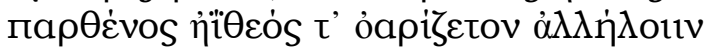

HOMERO, Miada, XXII. 126-128

No es momento ahora de partir de la encina y la piedra para dialogar amorosamente como una muchacha y un muchacho, como una muchacha y un muchacho que hablan entre sí en la intimidad.

El bucolismo implícito en la íntima conversación sugerida en el texto de Iliada, coloca a la épica en el contexto de una creación amorosa, el discurso del héroe es un monólogo pronunciado antes de morir, que el personaje intenta convertir en diálogo pacífico bajo la vulnerabilidad vital de la encina y bajo la invariabilidad firme de la roca. Vegetal y mineral sintetizan lo que se pretende modificar y lo inmutable. También en relación con estas dos dimensiones, la temporalidad del cambio vegetal

\footnotetext{
1 Sobre las modalidades discursivas en los poemas homéricos, Cfr. De Jong, 1987; De Jong, 2001 y Zecchin de Fasano, 2004

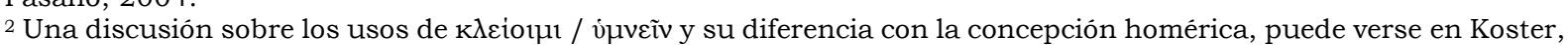
1970, p.8-9.

${ }^{3}$ Cfr. Peradotto, 1990, pp.68-72 quien diferencia entre profecía épica y oráculo trágico en que se vaticinan desgracias concretas. En la épica hay una serie de opciones en las que el sujeto puede ver oscilar su destino.
} 
y la inmutabilidad de la roca, la palabra del héroe implica un reconocimiento del tiempo inminente, del instante único de la muerte heroica. ${ }^{4}$ Los versos señalan la inminencia del tiempo, iniciar el diálogo desde la encina y la roca implica remontarse a los orígenes en un discurso genético para el cual la concatenación de acciones ha gestado sólo la salida del duelo. Merece destacarse que la misma imagen es usufructuada en el lento proceso de anagnórisis entre Penélope y Odiseo que culmina en el canto 23 de Odisea. El proceso se inicia en el canto 19 cuando Penélope interroga al mendigo sobre sus orígenes:

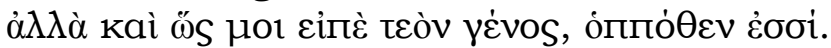

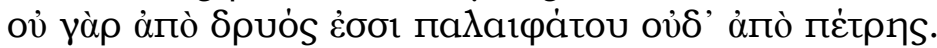

HOMERO, Odisea, 19.v.162-163

Sin embargo, aun asi dime tu estirpe, de dónde eres; pues no provienes ni de la encina ni de la roca del antiguo dicho.

El pasaje contiene una sofisticada ironía: el mendigo Odiseo lleva indicios de un linaje no desconocido y si el texto aduce al mito del origen de la humanidad a partir de estos elementos, la encina y la roca, una inferencia adecuada es que el personaje no tiene ese origen común, sino uno propio e identificable.

Naturalmente resulta tentadora la aplicabilidad al contexto rural hesiódico de la imagen, pero en ciernes la expresión contiene en ambos poetas un elemento de revelación a producir, ya sea la identidad individual, ya sea un contenido poético. ${ }^{5}$

Los versos 29 a 35 de Teogonía, ya citados, guardan estricta vinculación con las lineas anteriores en que las musas llaman a los pastores:

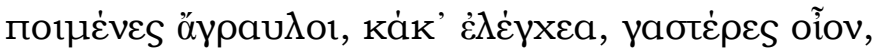

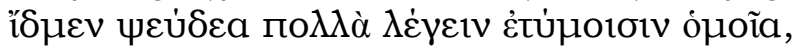

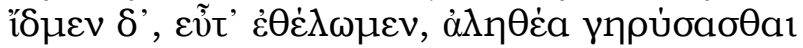

HESÍODO, Teogonía 26-28

¡Rústicos pastores, vergüenza indigna, tan sólo vientres! Sabemos decir muchas mentiras semejantes a verdades, pero también sabemos, si queremos, proclamar la verdad.

Las musas deciden la exclusividad y la exclusión de Hesíodo, el único pastor al que ellas se dirigen, el primero al que ordenan cantar y recibe una voz. La línea 27 contiene una reiteración -con versión alomorfa- del verso de Odisea 19.203 y establece que en el programa poético de Hesíodo, toda ficción proviene de un acto deliberado de las musas. Entre estas afirmaciones, la invocación a los pastores como vientres, resulta también una variación alomorfa de los relatos de Odisea. Como ha señalado PUCCI (1987, p.196, n.14) no hay una concepción uniforme en los poemas homéricos acerca del vínculo del poeta con las necesidades básicas, ya que en Odisea, el mendigo hambriento es el que ofrece como un aoidós conceder kléos al pretendiente Antínoo (17, vv.415-418). El valor de ser considerado un "vientre" despliega la necesidad del relato de ficción en Odisea. ${ }^{6}$ Los pastores "vientres" de Teogonía, imponen un auditorio apegado a las necesidades naturales, también instalan la

\footnotetext{
${ }^{4}$ Nagy, 2014, 8§15, denomina al momento del máximo heroísmo, el momento "apobático", es decir el instante en que el héroe adquiere la máxima gloria, generalmente coincidente con su muerte.

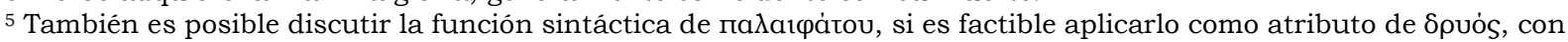
el sentido de "de una encina de antiguo renombre" o bien en la forma más tradicional, como si la frase integrara una antigua sentencia. Sobre las interpretaciones de este pasaje en Odisea, Cfr. Heubeck, 1992, p.83., De Jong 2001, p.468. Sobre la discusión del su valor en Homero y en Hesíodo, cfr. Verdenius, 1958, 20-24.

${ }^{6}$ Finkelberg, 1998, p.197 sostiene que las musas solo revelan la verdad sobre el pasado a sus favoritos.
} 
autoridad del único que lleva cetro y se encaminan al contexto rural de Erga, en que la voracidad y el hambre desarrollan una ideología póetica y política. ${ }^{7}$

La encina y la roca ofrecen una polaridad que puede brindar paisaje a la conversación amorosa como sucede en lliada, pero también permite desarrollar un discurso de linaje ligado al reconocimiento como sucede en Odisea. En su propósito de diferenciarse y separarse del hacer poético de Homero, Hesíodo utiliza esa polaridad entre lo vegetal y la piedra en la apertura de Teogonía con la escena pastoral de las musas danzando. Se trata de una naturaleza amable que contrasta notablemente con la tensión colérica del inicio de Ilíada o con el ignoto viajero que surge al inicio de Odisea.

La diferencia de matices con Homero despliega la polaridad en el ámbito en que el poeta Hesíodo contrasta con los hombres de su presente. El rústico pastor Hesíodo, sin embargo predilecto de las Musas, aprisionado por el decadente hierro de su presente, otra de sus polaridades dicotómicas, excluyó el efecto de encantamiento de la poesía. ${ }^{8}$

Consideremos nuevamente qué sentido tiene la pregunta hesiódica sobre la encina y la roca. En un famoso pasaje del Fedro de Platón, que dedica buena parte del diálogo a la discusión retórica sobre la calidad de los discursos, el valor de la escritura y la invención de la misma9 ${ }^{9}$, Sócrates expresa lo siguiente:

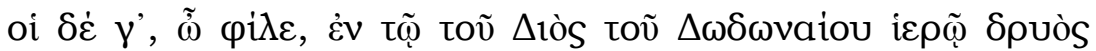

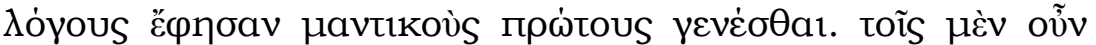

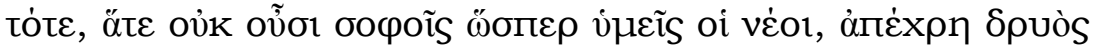

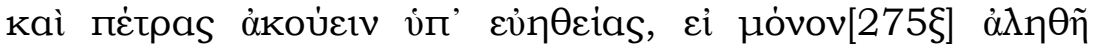

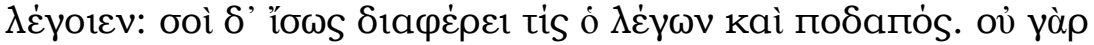

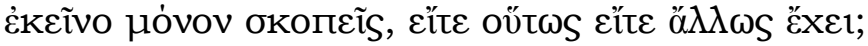

Y por cierto, amigo, quienes están en el templo de Zeus en Dodona dijeron que las de una encina fueron las primeras palabras proféticas. En efecto, para los hombres de entonces, que no eran sabios como ustedes los jóvenes, bastaba, por su ingenuidad, con escuchar a una encina o a una roca, con tal que dijesen verdad. Pero tú necesitas saber quién es el que habla y de qué país, y no te basta examinar si lo que dice es verdadero o falso.

PLATÓN, Fedro 275b 5

La encina y la roca constituyen el paisaje de la inspiración profética, el paisaje de la palabra ligada al porvenir, coligan lo natural vegetal y lo natural mineral. Ahora bien, en la escena de Ilíada en que Héctor imagina la íntima conversación amorosa con el enemigo, la encina y la roca circundan como naturaleza la producción de palabras que apunten al porvenir: evitar la muerte futura del guerrero.

Las razones de esta coincidencia entre elementos naturales que rodean la producción de la palabra, ya sea oracular, de personajes o poética, apela a la raíz misma de la tradición poética griega. Hay un sinnúmero de conexiones simbólicas entre la rama de árbol que contiene la vida del guerrero, el tierno brote que Tetis dice haber cuidado como madre de Aquiles y la encina que profetiza. ${ }^{10}$ Lo vegetal inserta

\footnotetext{
7 Sobre la póetica hesiódica asociada a la verdad, cfr. Zecchin de Fasano 2013, pp.875-881.

8 En Erga.106-202 Hesiodo se refiere a su propio tiempo como la edad de hierro, cuyo hombres tienen un corazón inconmovible caracterizado por la falta de respeto hacia los padres y hacia el pasado.

9 para lo cual Platón desarrolla el mito de Teuth.

10 Iliada, XVIII.54-60 y 437-441.
} 
al héroe en el mundo natural y lo hace cabal expresión de lo efímero. La palabra de la encina se diferencia en que instala una voz de autoridad más duradera.

La encina y la roca a las que Héctor imagina como paisaje antes de su final, lo constituyen de un modo irreal en la producción de palabras, ni siquiera el escenario profético habilita el diálogo. Hesíodo avanza sobre esto en relación con la producción de su propia palabra poética, en primer lugar al formular una interrogación acerca del significado de la encina y la roca como paisaje para la orden de las musas que le imponen cantar.

Como ya hemos mencionado, otros pasajes épicos dan cuenta del valor sentencioso de la frase, como en Odisea 19.163 cuando Penélope incita al cretense que Odiseo simula ser- para que mencione su estirpe y su lugar de origen y sostiene que él no puede alegar haber nacido de la encina o la roca como afirma el palaifatos, el dicho antiguo. Este tipo de conexión entre naturaleza y palabra arroja sobre Odiseo el reconocimiento de sus anclajes humanos, obviamente él debe tener patria y familia, pero, ¿no es al mismo tiempo, como personaje un resultado lingüístico? Lo que emiten la encina y la roca es lenguaje profético, lenguaje sobre el futuro, eso incluye además de una concepción de la poesía vinculada a un acto de habla, la composición del personaje en ese acto de habla.

\section{Cigarras, sirenas y musas}

En el sitio arqueológico de Delfos, el santuario de Apolo se halla acompañado en la temporada estival por el zumbido ensordecedor de las cigarras, acaso una realidad que explica la razón por la cual se instaló la tradición según la cual ellas representan la voz del dios. La referencia apolínea no es la única cuestión que colabora con la identificación entre cigarra y poeta, que se ve continuada en la célebre confrontación didáctica entre cigarra y hormiga, es decir entre el poeta y el artesano. ${ }^{11}$

Entre las primeras versiones miticas en las que una cigarra se halla involucrada, se encuentra el mito de Eos y de Titono, aunque Homero sólo lo menciona parcialmente. Eos o Aurora, enamorada de Titono solicitó su vida eterna, pero olvidó pedir su juventud. La eterna vejez de Titono se volvió insoportablemente atroz para Eos que se conformaba sólo con oírlo. El mito concluye con la conversión en cigarra del amante. ${ }^{12}$ Se cumple de este modo una atractiva simbiosis entre eros y palabra cuyas consecuencias aparecen incluso en el Fedro de Platón.

En otro pasaje homérico estrictamente vinculado a la composición de líada, la célebre teichoskopia, la visión del campo de batalla desde los muros de Troya se halla precedida por una imagen que conecta a los troyanos con las cigarras:

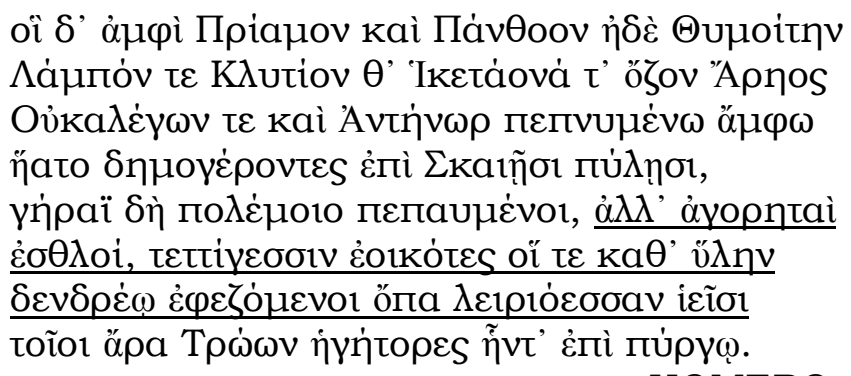

HOMERO, Iliada III, 146-153

\footnotetext{
${ }^{11}$ En la formulación de la fábula de Esopo 336, se trata de confrontar al laborioso con el holgazán, sin embargo en la tradición literaria griega resulta inevitable identificar a la cigarra-cantor con el poeta despreocupado de las necesidades básicas.

${ }^{12}$ El mito de Eos y Titono se halla atestiguado en Ilíada XI, 1 y ss., XX, 237, en Odisea 5, 1. También en Teogonía 371 y 984 . Por supuesto las versiones posteriores dependen de los resúmenes que aporta Apolodoro en su Biblioteca III, 12.3 .
} 
Los que estaban en torno a Príamo, Pantoo y Timetes, Lampo, Clicio e Hicetaón, retoño de Ares, Ucalegonte y Antenor, inspirados ambos, ancianos del pueblo, estaban sentados en las puertas Esceas. La vejez los habia retirado del combate. Sin embargo, eran consejeros valiosos, parecidos a las cigarras que, por el bosque posadas sobre un árbol, emiten su voz de lirio. Asi eran los lideres de los troyanos, sentados sobre la torre.

Esta equiparación entre los ancianos troyanos y las cigarras de voz de lirio, reúne como el mito de Titono, la vejez con la voz de la cigarra, pero aquí en el positivo sentido del consejo producido como voz leirióessan. La semejanza con el lirio se registra también para referirse a la piel del guerrero Áyax, a quien Héctor amenaza con desgarrar (Iíada, XIII.830) y para la voz de las musas (HESÍODO, Teogonía. 41). La tradición nos impone un esquema conceptual en que las cigarras se enfrentan a las laboriosas hormigas, y no resulta desechable que los troyanos se asimilen a las cigarras cuya florida voz, se verá cercenada por las huestes de Aquiles, numerosas como hormigas. En el nivel lingüístico y en la imaginería, la contraposición de las cigarras troyanas a los mirmidones-hormiga de Aquiles expone por anticipado el resultado de la batalla final de Iliada.

Otra referencia recurrente, e incluso más familiar, es la asociación de la cigarra con el calor estival en medio del cual produce su canto. En unos versos de Erga, Hesíodo realiza la descripción estacional, que asocia el florecer del cardo y el canto de la cigarra, en medio de un entorno pastoril, y de connotaciones eróticas:

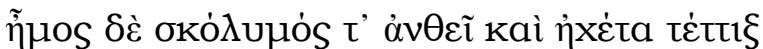

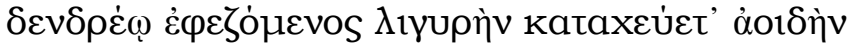

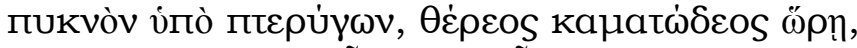

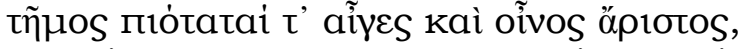

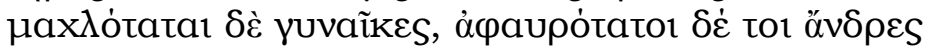

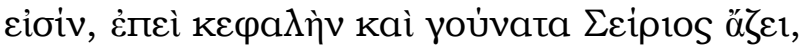

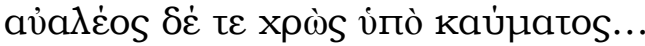

HESÍODO, Erga 582-587

Cuando el cardo florece y la estridente cigarra posada en el árbol, difunde su agudo canto, persistente bajo sus alas, es la estación del fatigante verano. Entonces es tiempo de cabras bien cebadas y de excelente vino, las mujeres son más sensuales y los hombres más débiles, porque Sirio inflama su cabeza y sus rodillas y la piel se reseca por el ardor...

La forma en que el léxico de Hesíodo modifica lo gárrulo de los consejeros troyanos en la aguda voz que llama al campesino a las tareas y placeres del verano, aporta una nueva formulación del vínculo entre eros y canto, eros y palabra.

Esa ubicación intersticial de la voz de la cigarra como expresión del florecer natural reaparece en la ubicación que Platón concede al mito de las cigarras en su diálogo Fedro. Como ha señalado CAPRA (2014) este diálogo presenta una estructura bipartita con una primera parte dedicada al eros y una segunda parte dedicada a la retórica. La vinculación entre ambas partes se efectúa a través del pasaje que actúa como puente y que contiene el mito de las cigarras. El pasaje completo ocupa los fragmentos 258e- 259d y se compone de dos breves discursos de Sócrates. En el primero, Sócrates atribuye a las cigarras la posibilidad de dialogar y observar a los 
humanos, y además, considera que ellas tienen capacidad de elegir conductas respecto de los hombres. Si ellos ceden muellemente al calor como animales serán considerados como esclavos. La comparación con los corderos es netamente peyorativa ya que convertiría a los humanos en un espectáculo cómico, presenciado por las cigarras. Sócrates afirma:

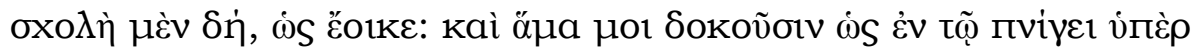

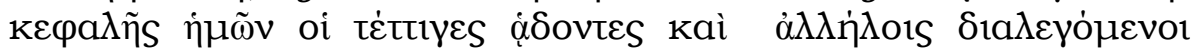

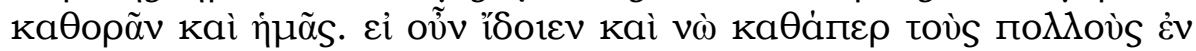

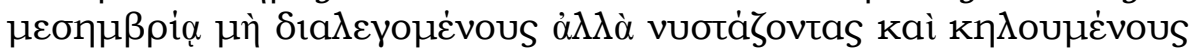

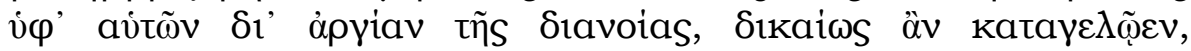

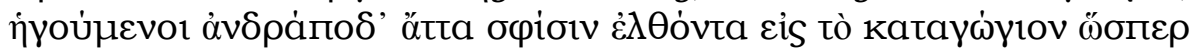

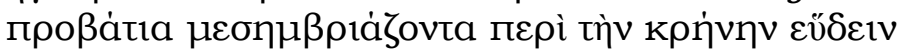

PLATÓN, Fedro, 258 e-259a

Tenemos tiempo según parece, y además tengo la impresión de que en medio del calor sofocante las cigarras, mientras cantan sobre nuestras cabezas y dialogan entre sí, también nos están mirando. Entonces si vieran que nosotros, como el común de los hombres, al mediodia no conversamos; sino que damos cabezadas y cedemos a su encanto, por pereza de espiritu, con razón se reirian, considerándonos unos esclavos que les llegaron a este rinconcito para dormir una siesta como ovejitas junto a la fuente.

Así como la capacidad de dialogar convierte a las cigarras en casi humanas, la continuidad del diálogo entre Sócrates y Fedro obtiene un resultado positivo:

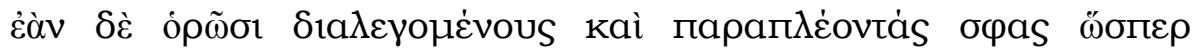

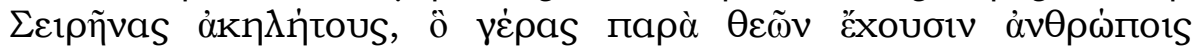

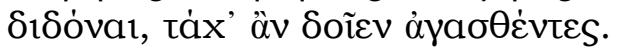

PLATÓN, Fedro, 259 b

Pero si acaso nos ven conversando y soslayándolas como a Sirenas, insensibles a sus encantos, quizá nos darian complacidas, el don que pueden otorgar a los hombres de parte de los dioses.

Obviamente, la sola mención de las sirenas y de Sócrates y Fedro como hábiles "Odiseos" que soslayan a las cigarras, sirve como prefacio al mito inventado por Platón. La asimilación entre cigarras y sirenas, se clarifica más adelante. Ambos seres tienen una naturaleza híbrida. Las cigarras han desarrollado una morfología diacrónica: han sido hombres en el pasado, pero no lo son en el presente. Las sirenas lo han hecho en forma sincrónica: son mitad femeninas, mitad aves. En Odisea, estas últimas conceden como don un tipo de sabiduría que consiste en saber los temas cantados por la poesía épica. Platón amplia su versión a un nivel poético más general, las cigarras-sirenas conceden un don de los dioses a los hombres, del cual Fedro se confiesa perfecto ignorante:

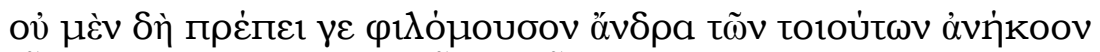

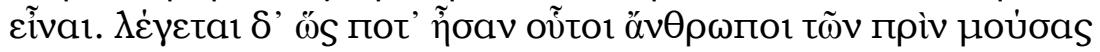

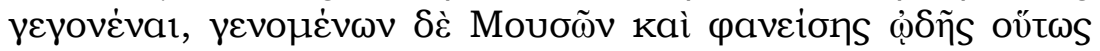

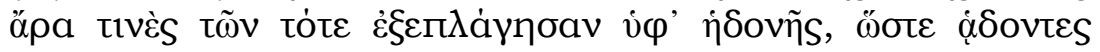

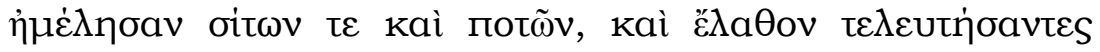




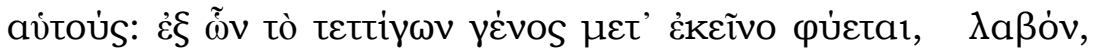

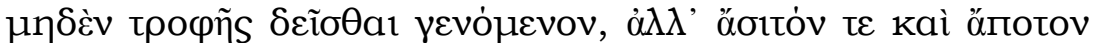

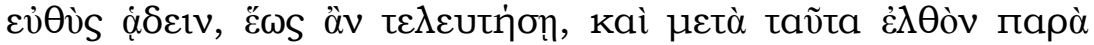

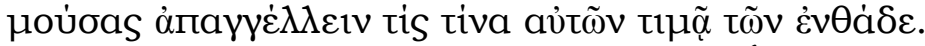

PLATÓN, Fedro, 259 b-c

Pues en verdad es impropio de un hombre amigo de las Musas no haber oido hablar de tales cosas. Se cuenta que, en otro tiempo, las cigarras eran hombres que vivieron antes de que las musas nacieran, pero cuando nacieron las musas y apareció el canto, algunos de los de ese entonces, quedaron tan transportados por el placer que, por cantar $y$ cantar, no se cuidaron de comer ni de beber y sin advertirlo, murieron. De ellos, nació después la raza de las cigarras, que recibió de las musas el privilegio, ni bien nacidas de no necesitar alimento alguno, sino el de ponerse a cantar, sin comer ni beber, hasta la hora de su muerte; y el ir después de su muerte, junto a las musas, para anunciarles quién de los de aqui les rinde honores y a cuál de ellas.

Como sostiene CAPRA, 13 el géras transferido de musas a cigarras es simplemente la inspiración poética. La coincidencia entre la fascinación producida por sirenas, musas y cigarras, aliena la necesidad de alimento, produce un olvido contrario a la memoria épica de las kléa andrón. El don de la poesía es el momento crucial de la iniciación poética, no sólo en los textos de Hesíodo y Platón citados, sino también en Arquíloco que encuentra a las Musas en la campiña de Paros o en Epiménides quien las encuentra después de cincuenta y siete años de largo sueño. Resulta indiscutible que tanto Hesíodo como Platón reformulan en la palabra géras el valor que ella tenía en Homero, especialmente en la Ilíada, en la que buena parte del relato se funda en los conflictos en torno a su obtención. En este sentido, Hesíodo $\mathrm{y}$, especialmente, Platón producen una sublimación "erótica" del géras, que pasa de simple don material a "palabra poética".

El texto platónico utiliza el contexto de la naturaleza para una simbiosis extraordinaria, tanto las sirenas como las cigarras, comparten el canto y la capacidad de producir olvido, pero las musas ofrecen algo diferente. Platón se separa del modelo paradigmático de la escena de iniciación poética en aspectos fundamentales. En primer lugar porque en vez de un poeta sólo en un ámbito natural, Platón presenta a dos amigos, que dialogan como para imitar a las cigarras y obtener su don. Además de ser un modo de llamar la atención sobre la cualidad dialógica de sus propios textos, el autor mencionará sólo a cuatro de las nueve musas: Urania y Calíope son las más filosóficas, por proteger la mousiké humana, es decir, la filosofia; luego Sócrates menciona a Erato y Terpsícore. Fedro es el único diálogo de Platón en el que Sócrates dice estar inspirado por distintos agentes: como Safo, Anacreonte y escritores en prosa (235 c), las musas (237 a), el paisaje, (que lo hace numphóleptos, 238 d), las ninfas que "entusiasman" a Sócrates (241d), o Ibico y Estesícoro (242b243d). Afirma, además, que las musas le llevan el alma a un frenesí báquico (245a); que lo inspiran las cigarras al traspasar a los hombres el don de las musas $(258 \mathrm{e}-$ 259d) y otros dioses locales (262c-d), incluso, Pan y las ninfas (ellas son superiores a Lisias,263d, cf.278d).

\footnotetext{
13 Capra 2014, p. 230, se expresa en sentido contrario a Kahn, no considera que Fedro exponga una suerte de desarrollo platónico hacia la dialéctica: "the cicada myth clearly highlights dialectics as dialogue rather than as the more specific procedure, based on the systematic division of concepts, typical of Plato's "late" works (or at least of some of them). Moreover, the myth appears to authorize both dialectics and myth: the cicadas and, indeed, any philosophers (potentially at least) who receive the "Muses' gift," both sing and dialogue".
} 
El modo en que el lenguaje metafórico expresa la presencia de estos inspiradores vuelve a servirse de la naturaleza, ya que todo el discurso de Sócrates se vuelve paisaje divino, al que fluyen los arroyos o corrientes que manan de todos los agentes y, en particular, de Safo y Anacreonte.

Sin duda, hay un número riquísimo de elementos para continuar el análisis de este diálogo, como la organización de los poetas en pares correspondientes, Anacreonte/Safo e Ibico/Estesícoro, identificados cada uno con Erato y con Terpsícore, respectivamente. ${ }^{14} \mathrm{La}$ asociación de Terpsícore con Estesícore como aparece en el famoso vaso de François y, en consecuencia, la identificación con el poeta Estesícoro y su palinodia, entre otros.

\section{Conclusiones}

En todos los elementos de la naturaleza citados, el común denominador es su condición fónica. La encina y la roca, transfieren un tipo de poesía profética, remontan a tiempos originarios, los troyanos-cigarra, proporcionan una ironía trágica, su voz durará poco tiempo, derrotada por los mirmidones-hormiga. Las cigarras hesiódicas, que señalan el verano a los campesinos e incrementan la voluptuosidad de las mujeres, encuadran perfectamente en la primera parte del Fedro, cuando Sócrates encuentra una amable pradera:

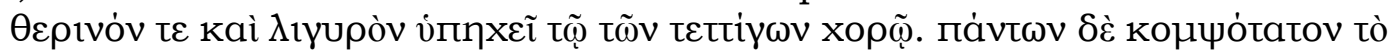

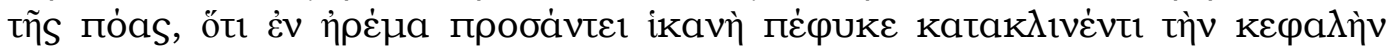

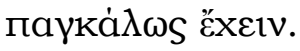

PLATÓN, Fedro, 230b2-c6.

¡Una clara melodía estival que se hace eco del coro de las cigarras! Pero lo más refinado de todo es el césped, porque en la suave pendiente que crece es apropiado tener la cabeza hermosamente reclinada.

Pero las cigarras-hombres del mito de Platón, que han tenido una existencia previa a la de las musas, que han escuchado a Fedro y a Sócrates argumentar acerca del amor y de la seducción de la palabra, esas a las que hay que soslayar como a sirenas, son ante todo un coro mediador y tienen algo para dar, y su don, si no es poesía, será, en todo caso, maravillosa conversación.

\section{REFERENCIAS BIBLIOGRÁFICAS}

AMEIS, K. F. \& HENTZE, C. Homers Mias. Amsterdam: Teubner, 1965.

AMEIS, K. F. \& HENTZE, C. Homers Odysee. Amsterdam: Teubner, 1964.

Buenos Aires, Losada, 2007.

BURNET, I. Platonis Opera. Oxford: Oxford University Press, $1901^{1}$.

CANEVARO, L. G. "Genre and authority in Hesiod's Works and Days" en WERNER, C., SEBASTIANI, B.B. e DOURADO LOPES, A. (ed) (2014). Géneros Poéticos na Grécia Antiga. Sâo Paulo: Humanitas, 2014, pp. 23-48.

CAPRA, A. "Lyric Poetry and its Platonic pedigree" en WERNER , C. , SEBASTIANI, B.B. e DOURADO LOPES, A. (ed) (2014) Géneros Poéticos na Grécia Antiga. Sâo Paulo: Humanitas, 2014, pp. 125-148.

CAPRA, A. "Plato's Four Muses: The Phaedrus and the Poetics of Philosophy". Hellenic Studies Series 67. Washington, DC, Center for Hellenic Studies, 2015.

\footnotetext{
${ }^{14}$ Sobre la vinculación de las musas con Safo y su epiteto "décima musa", cfr. Capra 2014, cap.3, passim.
} 
DE JONG, I. J. F. A Narratological Commentary on the Odyssey. Cambridge: Cambridge U. Press, 2001.

DE JONG, I. J. F. Narrators and Focalizers. The Presentation of the story in the Iliad. Amsterdam: B.R. Grüner, 1987.

FERRARI, G. Listening to the Cicadas. A study of Plato's Phaedrus. Cambridge: Cambridge University Press, 1987.

FINKELBERG, M. The Birth of Literary Fiction in Ancient Greece. Oxford: Clarendon Press, 1998.

HEUBECK, A. \&. HOEKSTRA, A. A Commentary on Homer's Odyssey. Oxford: Clarendon Press, 1990, Vol. II

HEUBECK, A., FERNÁNDEZ-GALIANO, M. \&. RUSSO, J. A Commentary on Homer's Odyssey. Oxford: Clarendon Press, 1992, Vol. III.

HEUBECK, A., WEST, S. \&. HAINSWORTH, J.B. A Commentary on Homer's Odyssey. Oxford: Clarendon Press, 1991, Vol. I.

http://nrs.harvard.edu/urn-3:hul.ebook:CHS_CapraA.Platos_Four_Muses.2014. http://nrs.harvard.edu/urn-

3:hul.ebook:CHS_NagyG.The_Ancient_Greek_Hero_in_24_Hours.2013.

KOSTER, S. Antike Epostheorien. Wiesbaden: Steiner, 1970.

LINS BRANDÂO, J. Antiga Musa. Belo Horizonte: Faculdade de Letras da UFMG, 2005.

NAGY, G. The Ancient Greek Hero in 24 Hours. Cambridge, MA: Harvard University Press, 2013.

PERADOTTO, J. Man in the Middle Voice. Princeton: Princeton University Press, 1990. PLATÓN. Fedro. Introducción, traducción y notas de M.I.Santa Cruz y M.I. Crespo, Buenos Aires, Losada, 2007.

PUCCI, P. Odysseus Polutropos. Ithaca: Cornell University Press, 1987.

TSAGALIS, Ch. The Oral Palimpsest. Washington, Harvard University Press, 2008.

VERDENIUS, W.J. "Hesiod 'Theogony' 35" Mnemosyne, Fourth Series, Vol. 11, Fasc. 1 ,1958, pp. 20-24

VIANELlO, P. (ed.) Hesiodo. Los Trabajos y los días. México: UNAM, 1979

WEST, M. L. (ed.) Hesiod. Theogony and Works an Days, Oxford, Oxford University Press, 2008.

ZECCHIN DE FASANO, G. C. "De Homero a Hesíodo: Disidencia y Congruencia en la antigua teoría del Epos" En: PINO CAMPOS, L.M. \& SANTANA HENRÍQUEZ, G, (EDS) Volumen Homenaje a Juan Antonio López Férez. Madrid: Ediciones Clásicas, 2013, pp.875-881.

ZECCHIN DE FASANO, G. C. Odisea: Discurso y Narrativa. La Plata: EDULP, 2004. 